\title{
A territorialização da residência secundária no litoral de Nísia Floresta (Rio Grande do Norte, Brasil)
}

\author{
The territorialization of the secondary residence in the coast of Nísia Floresta (Rio \\ Grande do Norte, Brazil)
}

\author{
Kelson de Oliveira Silva (SILVA, K. de O.) ${ }^{*}$
}

RESUMO - As primeiras residências secundárias no litoral de Nísia Floresta (Rio Grande do Norte, Brasil) surgiram na década de 1970, por iniciativa de veranistas da própria região. Entretanto, por volta dos anos 2000, ocorreram transformações na forma e no uso desse tipo de domicílio quando investimentos estrangeiros começaram a ser aplicados no setor imobiliário e turístico, produzindo empreendimentos de luxo, horizontais e verticais; servidos de infraestrutura de lazer/entretenimento, comércio, hotelaria e em alguns casos, servindo de domicílio fixo e/ou secundário, predominantemente comercializados para público estrangeiro. De acordo com os resultados da pesquisa em questão, pode-se afirmar que o direito de livre acesso e uso do litoral nisiaflorestense está comprometido devido a presença de residências secundárias, por negligência e omissão do poder público em não aplicar a legislação pertinente.

Palavras-chave: Ocupação do litoral; Turismo; Territorialidades.

ABSTRACT - The first secondary residences in the coast of Nísia Floresta (Rio Grande do Norte, Brazil) emerged in the 1970, by the initiative of local vacationers. However, around the 2000's, there were changes in form and use of this kind of place when foreign investment began to be applied in the real estate and the tourism, producing horizontal and vertical luxury ventures; which have all infrastructure for leisure/entertainment, commerce, hotels and in some cases, serving as first and/or secondary residence, predominantly commercialized to foreign public. According to the survey results, it can be said that the right of free access and use of the coast of Nísia Floresta is compromised by the presence of secondary residences, by negligence and omission of the authorities in not applying the legislation.

Key words: Occupation of the coast; Tourism; Territorialities.

\footnotetext{
" Graduação e Mestrado em Geografia pela Universidade Federal do Rio Grande do Norte (UFRN); professor nas especializações "Mídias na Educação" e "Gestão Ambiental" na Universidade do Estado do Rio Grande do Norte (UERN); professor da Secretaria de Estado da Educação (SEEC/RN), no Ensino Básico; bolsista do Curso de Geografia (UFRN), como tutor à distância. Endereço para correspondência: Rua Tenente Souza, 647, Pajussara. CEP: 59125-330 - Natal - Rio Grande do Norte - Brasil. Telefone: (84 ) 8815.7374. E-mail: kelsongeo@ hotmail.com
} 


\section{INTRODUÇÃO}

No litoral do município de Nísia Floresta (Rio Grande do Norte, Brasil), a expansão de residências secundárias tem implicado na ocupação de trechos da costa marítima, constituídos e assegurados por lei como de "domínio público", por serem de propriedade da União (SILVA, 2010). Em virtude da falta de planejamento urbano e da debilidade da atuação do poder público, no exercício legal dos instrumentos reguladores do uso do território, esse tipo de domicílio de uso ocasional - DUO (definição oficial do Instituto Brasileiro de Geografia e Estatística - IBGE), vem se reproduzindo desrespeitando o fundamento legal da Constituição Federal que estabelece a praia como sendo patrimônio do povo.

O direito de livre acesso e uso do litoral como bem público está garantido ao cidadão brasileiro pela Lei 7.661/88 (BRASIL, 1988) regulamentada pelo Decreto 5.300/04, no qual as praias são consideradas "bens públicos de uso comum do povo, sendo assegurado, sempre, livre e franco acesso a elas e ao mar, em qualquer direção e sentido" [...] (BRASIL, 2004).

A residência secundária tem sido apontada como sendo responsável por significativas transformações espaciais da zona costeira do Brasil, processo esse associado à valorização das áreas de praia, enquanto espaços de lazer e visitação. No que se refere ao mercado imobiliário e o turismo, essa valorização das áreas de costa tem fragmentado grandes e pequenas porções do litoral, privatizados para o uso turístico e do lazer. Nesse sentido, o presente trabalho tem como questão central, a seguinte problemática: quais as formas de privatização das áreas costeiras de propriedade da União, por residências secundárias? Considerando-se a questão - problema da pesquisa, o objetivo do trabalho é analisar como esse tipo de domicílio tem se apropriado dos acessos e áreas públicas de praia, no município de Nísia Floresta.

Sendo necessário ressaltar que o presente trabalho é parte de pesquisa de mestrado defendida no Programa de Pós-Graduação e Pesquisa em Geografia da Universidade Federal do Rio Grande do Norte - PPGE/UFRN, analisando a problemática da privatização das áreas costeiras de propriedade da União; pesquisa essa realizada com bolsa de mestrado concedida pela Coordenação de Aperfeiçoamento de Pessoal de Nível Superior - Programa de Apoio a Planos de Reestruturação e Expansão 
das Universidades Federais - CAPES/REUNI/UFRN. A pesquisa de mestrado em questão serviu de base para trabalhos publicados em alguns eventos acadêmicos, contribuindo com a discussão da relação entre espaço público e residência secundária.

Os procedimentos metodológicos foram divididos em quatro etapas: 1) levantamento e leitura bibliográfica, coleta e organização de dados secundários; 2) observação in lócus no qual se analisou as características físicas dos acessos públicos das áreas de praia, avaliando as condições das calçadas, iluminação pública, largura desses logradouros, estado de conservação e manutenção das ruas; 3) realização de entrevistas junto a Secretaria de Turismo e Meio Ambiente de Nísia Floresta; Secretaria de Tributação de Nísia Floresta; Instituto de Desenvolvimento Sustentável e Meio Ambiente do Rio Grande do Norte - IDEMA/RN; Gerência do Patrimônio da União no Rio Grande do Norte - GRPU/RN; e, moradores permanentes; e, 4) aplicação de questionário junto aos usuários de residências secundárias. Os questionários foram aplicados nas praias de Pirangi do Sul, Búzios, Tabatinga, Camurupim e Barreta, nos meses de janeiro e fevereiro do ano de 2010.

Para a aplicação dos questionários foi selecionada uma amostra de 107 veranistas, dos quais 75 veraneavam nas praias de Pirangi do Sul e Búzios e os demais nas praias de Tabatinga, Camurupim e Barreta. A coleta dos dados referentes aos detentores de residências secundárias deu-se por meio de questionário semiestruturado, com perguntas abertas e fechadas. Os moradores permanentes foram consultados através de entrevistas informais, nas quais se levantaram questões pertinentes aos conflitos entre a comunidade local e os veranistas, buscando com isso analisar em que a presença desses domicílios de uso temporário estava implicando no não exercício da cidadania da população fixa, com relação ao uso do espaço público litorâneo. Para a fundamentação jurídica, tomou-se como referência o art. 10, da Lei 7.661/88 (BRASIL, 1988) por estabelecer que as praias são "bens de uso comum do povo".

Diante da preocupante forma de ocupação do litoral brasileiro, surge o Projeto de Gestão Integrada para a Orla Marítima - Projeto Orla (OLIVEIRA; NICOLODI, 2012; BRASIL, 2006), que se constitui em ação conjunta entre o Ministério do Meio Ambiente (MMA), e o Ministério do Planejamento, Orçamento e Gestão (MPOG), no âmbito da Secretaria do Patrimônio da União (SPU), buscando implementar uma 
política nacional que harmonize e articule as práticas patrimoniais e ambientais, com o planejamento do uso e da ocupação da costa brasileira.

\section{RESIDÊNCIA SECUNDÁRIA - ASPECTOS CONCEITUAIS E ANTECEDENTES HISTÓRICOS}

No Brasil, a residência secundária tem se constituído elemento urbano presente no campo e na cidade, sendo importante fator de urbanização dos lugares apropriados. No litoral, em virtude da preferência pelo modelo sol e mar, as praias próximas aos centros urbanos se converteram em reduto de residências secundárias visitadas nos fins de semana, feriados e férias anuais. Nesse sentido, "muitas vezes a ocupação do litoral por residências secundárias foi responsável pela incorporação da praia à tessitura urbana" (SILVA, 2009, p. 4).

Conceitualmente, a definição de residência secundária de Tulik (2001) coloca esse tipo de imóvel como sendo um alojamento turístico particular, utilizado temporariamente nos momentos de lazer, por pessoas que tenham outro domicílio de uso permanente. Igualmente afirma que a frequência do uso desse tipo de domicílio está expressa na relação tempo-custo-distância, uma vez que seus usuários precisam estabelecer certa regularidade entre saídas, chegadas e retornos.

Quanto aos custos, a aquisição de uma residência secundária implica gastos com sua construção, manutenção, despesas de pessoal, impostos, serviços públicos e o deslocamento até o local de férias ou descanso. Conforme coloca Tulik (2001, p. 11), “[...] ter uma residência secundária significa possuir disponibilidade financeira, até mesmo para chegar ao destino, pois, implica, na maioria das vezes, a posse de veículos ou, com menor frequência, a utilização de transportes coletivos".

O tempo livre é outro fator importante no que diz respeito ao veraneio, de forma que os fins de semana são convertidos em um fato social apropriado para o uso da residência secundária (ASSIS, 2003). O mesmo autor comenta que geralmente os veranistas iniciam suas migrações com destino ao lazer em seus domicílios temporários na sexta-feira à noite ou no sábado pela manhã, retornando quase sempre no domingo à tarde. Nessa perspectiva, a possibilidade de dispor de tempo livre nos fins de semana, 
segundo Tulik (2001), representa uma conquista social, favorecendo diferentes camadas da sociedade que passaram a usufruir da possibilidade de adquirirem uma residência secundária.

O uso de residências secundárias teve sua origem no hábito dos povos europeus de passarem períodos mais ou menos longos distantes da casa principal, tendo como motivo básico descansar distante dos aglomerados humanos (SILVA, 2009). Camargo (2007), afirma que é provável encontrar uma série de costumes e hábitos existentes no Alto Império Romano, tais como de visitas frequentes a sítios e lugares que se poderiam chamar de veraneio. Práticas sociais essas, restritas a pequena parcela do Império, e que sugerem o uso de residências secundárias já àquela época.

Segundo Corbin (1989), a elite romana apreciava passar períodos de descanso em suas vilas nas praias, de forma que do final da República até a metade do segundo século do Império, multiplicaram-se as estações balneárias às margens do Lácio e da Campânia. O autor comenta que figuras históricas da Roma Antiga, como César, Pompeu, Antonio e Cícero, possuíram villas nos arredores de Pozzuoli. Conforme Corbin (1989, p. 268), eles chegavam durante a temporada de descanso, de preferência na primavera, a fim de "encontrar aí o frescor e tomar banhos sulforosos".

Ao longo de toda Idade Média, os reis construíram residências secundárias nas montanhas, próximo aos rios e lagoas (COLÁS, 2003). Na ocasião da estadia nesses domicílios de veraneio, os monarcas praticavam esportes tradicionais como a pesca e a caça, permanecendo, em alguns casos, longo período de tempo distante da corte, o que motivava a inquietação dos seus súditos. Boyer (2003), afirma que na Itália, data do século XVI o início da construção das primeiras mansões de verão em torno das cidades italianas, a exemplo das vilas paladianas de Brenta e que em função de seu uso sazonal são consideradas residências secundárias, de propriedade da burguesia imperial europeia.

De acordo com Silva (2009), no Brasil Colônia o costume de passar temporadas em casas de verão, palacetes, bangalôs, quintas e chácaras, no campo ou na cidade, é resultado de desdobramentos sociais e também econômicos, associados à presença dos monarcas portugueses e de sua corte. No Rio de Janeiro, no século XIX, as famílias mais abastadas frequentemente tinham residência secundária em sítios e ou fazendas afastadas do centro da cidade, onde passavam longas temporadas, recebiam hóspedes e 
promoviam recepções (VILLAÇA, 2001). O autor prossegue afirmando que esses domicílios, normalmente se localizavam no continente, em áreas rurais, dado o fato que até então o mar se constituía em local pouco apreciado pelos nobres. Conforme De Jesus (1999, p. 7), “as praias eram utilizadas basicamente como depósito de dejetos urbanos, e para coletas de mariscos e pesca pelos setores socialmente marginalizados".

No Rio Grande do Norte, o litoral natalense passou a se constituir em local de lazer e veraneio marítimo no início do século XX (SILVA, 2009). Miranda (1999, p. 61) comenta que pela Resolução Municipal no 115/1908, a Intendência Municipal de Natal, em 1908, oficializou Areia Preta como balneário de banhos da cidade, escolhida por ser "a praia que melhores condições oferecia para os banhos de mar". De acordo com Silva (2009), a partir de 1915, quando uma linha de bonde chegou à praia de Areia Preta, esse trecho do litoral natalense, aos poucos deixou de ser local de pesca e gradativamente transformou-se em reduto de veraneio, visitado por alguns poucos banhistas e moradores de residências secundárias.

Entretanto, o fenômeno do veraneio no Rio Grande do Norte somente ganhou maior expressão a partir das décadas de 1960/70, quando as praias vizinhas a Natal, nos municípios de Parnamirim e Nísia Floresta, começaram a ser ocupadas por residências secundárias (LOPES JUNIOR, 2000). Fonseca (2005) afirma que a residência secundária, nesse sentido espaço-temporal antecedeu a entrada do turismo no Rio Grande do Norte, que tem na construção do Parque das Dunas/Via Costeira seu marco fundador, inaugurado na década de 1980.

\section{ESPAÇO PÚBLICO - CONTRIBUIÇÕES CONCEITUAIS}

Os termos "público" e "esfera pública", segundo Habermas (2003), têm múltiplos significados concorrentes e que se originaram de diferentes momentos históricos. Segundo o autor, os termos "público" e "privado" são categorias de origem grega, transmitidos em sua versão romana, de forma que na cidade-estado grega desenvolvida, a esfera da polis que é comum aos cidadãos livres (koiné) é rigorosamente separada da esfera do iokos, que é particular a cada indivíduo (idia). 
O que atualmente denomina-se de privado é um círculo de intimidade cujos primórdios encontram-se nos últimos períodos da civilização romana, conforme Arendt (2005, p. 48), no qual qualquer pessoa que vivesse unicamente uma vida privada - o homem que, como o escravo, não podia participar da esfera pública ou que, como o bárbaro, não se desse ao trabalho de estabelecer tal esfera - "não era inteiramente humano". Nesse sentido, Arendt (2005, p. 51) afirma que a esfera pública se constituía tão importante que "Pertencer aos poucos iguais (homoioi) significava ter a permissão de viver entre os pares" [...]. Para Arendt (2005, p. 64), "Se o mundo deve conter um espaço público, não pode ser construído apenas para uma geração e planejado somente para os que estão vivos: deve transcender a duração da vida de homens mortais", postergando aos seus descendentes uma sociedade democrática e livre, na qual todos possam se manifestar e gozar de direitos igualitariamente.

A ausência da participação popular no exercício da cidadania e por sua vez na efetivação do direito ao espaço público, é para a Arendt (2005, p. 68), a privação da "privatividade" que reside na ausência de outros, no qual para estes, "o homem privado não se dá a conhecer, e, portanto é como se não existisse". Ainda, segundo o autor, a capacidade de participar criticamente do processo político da cidade, imbuído da ideia de manter a cidadania, e assim zelar por direitos, requer uma condição formada externamente, mas também intrínseca ao cidadão, de modo que, é privilégio de poucos a ação de pensar.

No Brasil, as primeiras definições de espaço público, surgiram ainda no período colonial, com o Bona Civitaris de acordo com Yázigi (2000), no qual os juristas indicavam três categorias de bens de interesse público: a) os de uso geral, tais como praças, pontes, sistema viário, fontes, jardins; b) os de propriedade pública: edifícios públicos; pastagens e cultivos comuns; c) os usualmente administrados pelo poder municipal ou arrendados em proveito do Conselho, tais como imóveis de uso específico, áreas especiais. $\mathrm{O}$ autor comenta que nesse documento, que basicamente era a legislação geral de Portugal e suas colônias, incluíam-se os Loca publica, espaços urbanos não especificados (campo incultos, cultura e pastagem), e os Loca publica, de designação precisa (edifícios, ruas, aquedutos, fontes, muros).

Quanto ao Estado e sua relação com o espaço público, Gomes (2002), coloca-o como única entidade social que cria e dispõe meios para estabelecer e outorgar o 
exercício pleno e verdadeiro da cidadania. O espaço público está sob domínio do Estado e apropriado para garantir os direitos sociais, remetendo-se sempre à concretização da cidadania, enquanto, espaço coletivo, segundo Silva (2008), embora livre à circulação de todos, não tem como finalidade o exercício pleno e efetivo da cidadania e do bem estar do cidadão.

De acordo com Gomes (2002, p. 161) a relação do Estado com o espaço público, em grande parte, tem sido de apropriação parasitária pela ação demagógica dos seus membros, de forma que a "mídia criticamente dócil" atua tendo em vista tornar pacífica a massa popular, tudo isso resultando na transformação de toda discussão social em espetáculo. Acrescentando ainda que "o desafio é, portanto, o de retomar o espaço público como lugar de uma participação ativa, normatizada e refundá-lo como um espaço da política".

O espaço público não se restringe somente ao conjunto de formas materiais e a sua natureza legal, mas abarca ainda uma dimensão subjetiva, na esfera política e sociocultural. Gomes (2002, p. 161), insiste para que seja considerada a perspectiva imaterial e material do espaço público. Em função dessa complexidade do espaço público, ser composta de atributos físicos e materiais, Serpa (2007), afirma que discutir o papel dessa categoria de análise na cidade contemporânea constitui-se em desafio, não somente para a Geografia, mas igualmente para as outras ciências políticas, embora, segundo ele, pouco tenha a Geografia se ocupado com a discussão do espaço público urbano.

Serpa (2007) defende a ideia de que não se pode separar forma e conteúdo quando se estuda o espaço público, para ele, esses dois elementos são a um só tempo, produtos e processos, portanto, indissoviáves. O autor considera a noção de cidadania e da ação política, necessárias na abordagem do espaço público, tanto quanto o conceito geográfico de acessibilidade. Igualmente, que a acessibilidade está estreitamente vinculada à demarcação dos territórios urbanos, à alteridade, contrapondo uma dimensão simbólica (e abstrata) à concretude física dos espaços públicos.

Ao se buscar definir a materialidade do espaço público, é necessário considerar que fisicamente, o espaço público é, antes de tudo, o lugar, a praça, a rua, o shopping, a praia, qualquer tipo de espaço onde não haja obstáculo à possibilidade de acesso e participação de qualquer tipo de pessoa. Essa condição deve ser uma norma respeitada e 
revivida, a despeito de todas as diferenças e discórdias entre os inúmeros segmentos sociais que aí circulam e convivem, ou seja, as regras do convívio e do debate devem ser absolutamente respeitadas (GOMES, 2002).

Nesse aspecto, a existência do espaço público está condicionada às relações sociais, sendo por intermédio da civilidade, seu emprego e uso, que surge a possibilidade de diálogo, operando-se as transformações fundamentais à vida social democrática. Para Gomes (2002), o espaço público é assim a mise-em-scène da vida pública, desfile variado de cenas comuns em que se exercita a arte da convivência, de forma que o lugar físico orienta as práticas, guia os comportamentos, e estes por sua vez reafirmam o estatuto público desse espaço, e dessa dinâmica surge uma formaconteúdo, núcleo de uma sociabilidade normatizada e consubstanciada no espaço público.

\section{A RESIDÊNCIA SECUNDÁRIA EM NÍSIA FLORESTA}

O fenômeno da residência secundária no município de Nísia Floresta teve início quando o turismo potiguar ainda era residual e sem expressão espacial enquanto atividade econômica. De acordo com Brito et al., (1993), o litoral desse município inicialmente passou ser ocupado por proprietários de residências secundárias, majoritariamente de origem da capital do estado ou de cidades adjacentes a Natal.

A pesquisa de Brito et al. (1993), identificou que na Praia de Búzios, entre os anos de 1977 e 1983 foram registrados 22 loteamentos, sendo que em 7 deles o vendedor foi simultaneamente o loteador das terras; em 6 casos, o vendedor somente vendeu terras; em 2 casos de pessoas jurídicas, o vendedor representou concomitantemente a condição de vendedor e loteador. Igualmente a referida pesquisa, constatou que em duas situações, terras pertencentes ao Estado e a União, foram doadas e posteriormente loteadas. O mesmo autor afirma que o Jardim Atlântico, com $582.223,50 \mathrm{~m}^{2}$, loteado pela Imobiliária Atlântico Ltda., em 1979, foi o loteamento com maior área quadrada registrada em cartório, no qual constam cadastrados 800 lotes.

Muitos problemas alusivos aos encaminhamentos legais de tais loteamentos foram observados por Brito et al. (1993), no qual destacam-se: a) erros na localização 
dos loteamentos em relação aos pontos cardeais; b) falta de informações adequadas sobre dados relevantes dos loteamentos; c) ausência de croquis e de informações para detecção do loteamento na planta, entre outros.

Brito et al. (1993) observou a existência de vários "desmembramentos" na praia de Búzios e Tabatinga, evidenciando a flagrante negligência do poder público municipal no controle do uso e ocupação do solo urbano. Para o autor, tais desmembramentos não devem ser considerados legais, por se tratarem de iniciativa sem a observância mínima das exigências legais referentes ao parcelamento do solo, não estando registrado em cartório, portanto, se constituindo em infração ao parcelamento do solo urbano.

A ocupação por residências secundárias se deu em lotes totalmente irregulares, sobre áreas de paleodunas sem qualquer critério urbanístico, resultando em sérios danos paisagísticos e na apropriação de áreas da marinha (BRITO et al., 1993). O autor comenta que em 1992, já eram cerca de 2.000 imóveis ocupando a praia de Búzios, entre residências secundárias, hotéis, bares e restaurantes, resultado da intensa especulação imobiliária nesse trecho do litoral de Nísia Floresta.

A população residente na praia de Búzios denunciou empresas do setor imobiliário por construções de empreendimentos residenciais e turísticos em áreas de dunas, reforçando os apontamentos de Brito et al. (1993) quanto a ocupação desse trecho do litoral potiguar (CONSTRUÇÃO DE RESIDÊNCIAS EM BÚZIOS DESTRÓI DUNAS, 2007). Conforme a referida matéria jornalística constante na fonte acima, por falta de controle e fiscalização por parte do poder público municipal, a expansão de residências secundárias tem sido responsável pela redução da vegetação que fixa os sedimentos, de forma que os ventos carreiam os grãos de areia, depositados ao longo da via de circulação de veículos e de pedestres, como também nas casas dos moradores e veranistas da referida praia, sendo um dos motivos de insatisfação de ambos os agentes sociais.

A implantação à beira mar dessas residências secundárias, conforme Lopes Junior (2000, p. 41), deu-se de forma "ambientalmente desastrosa", implicando a ocupação de áreas frágeis, como de mangues, dunas e lagoas. Para Lopes Junior (2000, p. 40-41), as "casas de veraneio" são a marca da ocupação do litoral brasilerio, consideradas também por Moraes (2007, p. 38), como "o fator numericamente mais expressivo da urbanização litorânea" do país. 
Lopes Junior (2000, p. 41), afirma que a partir da praia de Ponta Negra seguindo em direção as praias de Cotovelo, Pirangi do Norte, Pirangi do Sul, Búzios até Tabatinga, uma "franja" de casas de praia disputa o território litorâneo, impondo uma nova dinâmica social às vilas de pescadores localizadas no entorno desses dois novos núcleos de residências secundárias.

Investimentos internacionais são canalizados para a produção de residências secundárias, associando o setor turístico com o imobiliário, de acordo com Ferreira e Silva (2007) colocam que, o antigo padrão de ocupação e uso do litoral por casas de veraneio, começou a ser substituído nos meados da década de 1990, por empreendimentos imobiliários fechados, atendendo a demandas externas.

Três fatores que contribuíram para a entrada do capital imobiliário internacional na produção de residências secundárias no litoral oriental potiguar são apontados por Fonseca (2007): o primeiro - técnico, por motivo do encurtamento das distâncias, na medida em que os meios de transporte tornaram-se mais rápidos; bem como a maior facilidade no acesso à informação possibilitando a divulgação dos produtos turísticos colocados no mercado e a diminuição nos custos das viagens; e o segundo - econômico em razão da reestruturação econômica que implicou no desenvolvimento de serviços que se caracterizam pela sua imaterialidade e intangibilidade, em que se inclui grande parte dos serviços oferecidos pelo segmento turístico; e o terceiro - político quando se observa a proliferação de políticas públicas com a finalidade de alavancar a atividade turística.

Essa nova dinâmica que associou o setor turístico e imobiliário ocorreu favorecida pelos investimentos do Programa de Desenvolvimento do Turismo no Rio Grande do Norte - PRODETUR/RN em obras estruturantes como o Aeroporto Internacional Augusto Severo e os eixos viários que facilitaram o acesso turístico às praias ao sul de Natal (FONSECA, 2007). De acordo com o autor, inicialmente esses investimentos migraram para Parnamirim e Nísia Floresta, em razão da escassez do solo urbano da capital, onde o litoral se encontrava saturado.

Segundo Ferreira e Silva (2007), com a criação da Zona Adensável e as obras de urbanização do Bairro de Ponta Negra, favoreceu-se o mercado imobiliário que elevou o preço do $\mathrm{m}^{2}$ dos terrenos, provocando uma corrida por edificações, consequentemente implicando na escassez de solo à beira mar disponível para a construção civil. 
Ferreira e Silva (2007) identificaram 376 empreendimentos imobiliários loteamentos, condomínios fechados, flats, resorts - em licenciamento, já licenciados e/ou em execução, referentemente ao ano de 2006. O município de Nísia Floresta, nesse mesmo ano, de acordo com os autores, contava com 74 desses empreendimentos de residências secundárias localizados no litoral.

Com relação à ocupação do litoral de Nísia Floresta, a praia de Búzios tem se destacado por apresentar um intenso avanço de residências secundárias, tanto individualizadas como igualmente agrupadas na forma de condomínios horizontais fechados. Nesse sentido, observa-se uma intensa ocupação da praia de Búzios, por domicílios e condomínios de residências secundárias que se instalaram, a princípio, ainda na década de 1970, sem que o poder público atentasse pelo ordenamento do solo urbano (SOUSA, 2005). O autor coloca que da relação da Prefeitura de Nísia Floresta em 2001, dos 28 loteamentos registrados, nenhum constava com licença ambiental; dos 58 empreendimentos licenciáveis identificados em Búzios, em 2003, apenas 5 estavam requerendo a licença ambiental; dos 1.030 processos requerendo licença ambiental no Instituto de Desenvolvimento Sustentável do Meio Ambiente do Rio Grande do Norte IDEMA/RN, entre 1980 e 2003, somente 8 eram de Búzios, porém, nenhum com a licença de operação.

De acordo com Silva (2009), a construção da Rota do Sol (Rodovia RN-063), interligando Natal às praias de Parnamirim e Nísia Floresta, a partir da década de 1990, intensificou a produção de residências secundárias, beneficiando o setor imobiliário ao dotar com infraestrutura rodoviária, esse trecho do litoral oriental potiguar. Conforme Souza (2005), com o melhoramento da Rota do Sol e a construção do Binário, executadas com recursos do PRODETUR/RN $\mathrm{I}^{1}$, acelerou-se a incursão pelas praias adjacentes e a "ativação das fraudes fundiárias", tendo em vista que os empreendedores perceberam a negligência e a omissão dos órgãos fiscalizadores, entre eles, a Prefeitura de Nísia Floresta.

\footnotetext{
${ }^{1}$ O PRODETUR/RN I beneficiou seis municípios potiguares: Natal, Parnamirim, Ceará Mirim, Nísia Floresta, Extremoz e Tibau do Sul. Os investimentos em infraestrutura foram realizados entre os anos de 1995 a 2002 (FONSECA, 2005, p. 123).
} 


\subsection{PRIVATIZAÇÃO DAS ÁREAS COSTEIRAS EM NÍSIA FLORESTA - RESULTADOS}

Nísia Floresta detinha, em 2010, a segunda maior quantidade de residências secundárias entre os municípios da Região Metropolitana de Natal - RMN, com 5.674 domicílios de uso ocasional - DUO, sendo que Natal se constitui no município potiguar com a maior quantidade desses domicílios (5.850) e Extremoz, Parnamirim e CearáMirim, detinham 4.354, 4.018, 1.858, respectivamente (IBGE, 2011). Juntos, os municípios da RMN agrupavam 21,754 residências secundárias, o que representava $33 \%$ de todos os DUO recenseados no Rio Grande do Norte. Esse fato reforça a centralidade dos municípios beneficiados pelo PRODETUR/RN dotados com uma série de obras de infraestrutura urbana, majoritariamente aplicados na capital potiguar.

Verifica-se que as residências secundárias no litoral oriental potiguar estão predominantemente concentradas no entorno metropolitano de Natal, principal polo emissor dos usuários desses domicílios, destacando-se Natal, Nísia Floresta, Extremoz, Parnamirim e Ceará-Mirim com os maiores percentuais de DUO. Esse fato está associado a infraestrutura urbana de Natal e a sua influência sobre os municípios adjacentes, atraindo o capital privado que se associou ao setor turístico na produção de residências secundárias.

Ao longo de todo litoral nisiaflorestense, constatou-se formas diversas de apropriação privada do espaço público, principalmente por residências secundárias, tornando dificultoso o livre acesso à praia e em alguns casos, impedindo a passagem de não residentes desses domicílios. As formas de apropriação privada dos espaços públicos litorâneos observadas pela pesquisa são: decks; piquetes; muretas; construções de residências secundárias e barracas em áreas públicas; correntes e cercas; acessos estreitos e/ou a ausência dessas vias, distribuídos no litoral de Nísia Floresta.

Entre as formas de apropriação privada dos acessos públicos da praia, a pesquisa identificou a edificação de decks nos quais os proprietários de residências secundárias estendem "sua propriedade" construindo plataformas com jardins, mesas com bancos, energia elétrica, água e iluminação de usos restritos aos seus proprietários.

Esses decks servem de mirantes dos proprietários desses domicílios de verão, sendo o local onde a família e seus amigos mais íntimos se reúnem nos finais de 
semana, feriados e férias. Em alguns casos, observou-se a presença de cercas, muretas e portões com cadeados impedindo a entrada de "estranhos" a esses espaços públicos privatizados. Os decks são territorialmente as áreas dos veranistas, de forma que os moradores locais não ultrapassam as barreiras físicas ou imaginárias, impostas pelos proprietários de residências secundárias.

Em Tabatinga, Camurupim e Barreta, embora não se tenha observado a presença de correntes e cercas fechando a passagem de pedestres; residências secundárias e barracas construídas em áreas públicas, muros, acessos estreitos e mal conservados, bem como a ausência deles, decks e muretas são as formas de privatização do espaço público litorâneo, identificados pela pesquisa nessas três praias.

Os moradores permanentes da praia de Pirangi do Sul ocupam predominantemente as áreas próximas da desembocadura do rio Pirangi, dispondo apenas de uma única via "oficial" de acesso à praia. Via essa em condições de acessibilidade comprometidas em razão de ser estreita, mal conservada, sem sinalização visual com informações de interesse público, com iluminação pública precária, e suja. No período da alta estação, essa via de acesso torna-se congestionada em razão do grande fluxo de veranistas, turistas e moradores locais transitando em busca da praia. As condições de estacionamento para veículos são limitadas e a rua não tendo pavimentação em todo seu trecho até a praia.

Outros meios de acesso à praia estavam sendo feitos de forma "clandestina", por dentro de propriedades particulares e ou por dentro de áreas alagadas de mangue, onde os moradores traçaram "veredas" para encurtar o caminho até o mar. Essa dificuldade de acesso à praia não é enfrentada pelos proprietários de residências secundárias desse trecho do litoral de Nísia Floresta, considerando-se que esses imóveis estão predominantemente localizados na primeira linha de mar, de forma que os usuários acessam o imóvel pela rua de trás, dispondo do privilégio da vista do oceano Atlântico.

Os veranistas não mencionaram considerar a dificuldade de acesso à praia ou a privatização do espaço público litorâneo como problema presente em Pirangi do Sul, conforme se observou por meio de conversas informais. Alguns apontaram que a limitação de acessos públicos à praia seria um fator positivo na medida em que mantinha as praias com número reduzido de banhistas. Essa opinião reforçou a ideia da existência de conflito social entre os moradores permanentes e veranistas. 
Segundo os resultados dos questionários aplicados, cerca de $85 \%$ dos veranistas de Nísia Floresta não consideraram que o morador permanente tinha o acesso dificultado às áreas de praias, em razão de algum tipo de privatização do espaço público. Em relação à opinião dos veranistas quanto à possível dificuldade que os mesmos teriam de acesso à praia, devido à privatização do espaço público litorâneo, mais de $87 \%$ afirmaram que não tiveram dificuldades de acesso às áreas de praias. Os que se manifestaram positivamente a respeito dessa questão alegaram que as principais dificuldades são: poucos acessos à praia; ruas mal conservadas e em condições de circulação comprometidas.

Outra forma de apropriação dos espaços públicos litorâneos é impedindo a passagem de não residentes de casas de veraneio, fechando a rua com correntes. Observou-se que em outra situação, os proprietários de residências secundárias impedindo a passagem de "estranhos" fechando a rua com cerca de arame farpado. Consultando o motivo do fechamento do acesso acima citado, o caseiro de uma residência secundária, respondeu que "não estava fechado não", segundo ele, qualquer pessoa poderia entrar ou sair. Acrescentando que a corrente servia apenas para evitar tentativas de estacionarem carros naquela rua.

Uma das formas evidenciadas de inibir a presença de "estranhos" nas áreas públicas litorâneas, adotada pelos veranistas, é por meio da instalação de piquetes em pontos estratégicos. Embora que os piquetes não impeçam a circulação e passagem dos transeuntes, constitui-se em delimitação territorial de uma área pública, em benefício de particulares. Essa função deveria estar reservada ao poder público e na medida em que os proprietários de residências secundárias tomam essa iniciativa, torna evidente a fragilidade do Estado no controle do espaço público que lhe foi confiado.

O descaso com os acessos à praia, por parte do poder público municipal não se restringe apenas a preservação do direito de livre acesso ao mar. Por falta de manutenção sistemática, verificou-se "ruas" completamente sujas, sem piso, calçadas e cobertas de mato por não ser feita a devida manutenção, regularmente. Segundo se constatou nas entrevistas realizadas com os veranistas, eles mesmos contratavam particulares para fazerem a limpeza das ruas algumas semanas antes do período de férias. Observou-se que a coleta de lixo no litoral, por parte do Município, estava deficiente e não ocorria com regularidade, constrangendo o veranista a se submeter a 
jogar seu lixo nos terrenos baldios ou levar os resíduos domésticos até um coletor público mais próximo. Essa opinião também foi compartilhada com os moradores permanentes, embora que nas praias de Pirangi do Sul, a coleta de lixo estivesse ocorrendo três vezes por semana, segundo os moradores entrevistados.

Conforme se observou, as áreas costeiras de propriedade da União no litoral de Nísia Floresta não estavam recebendo o devido e necessário cuidado por parte do poder público, ente institucional responsável pelo ordenamento territorial da cidade. Vias estreitas, tortuosas, obstruídas, sujas, cobertas por matagal, sem iluminação pública adequada, sem calçadas, pisos desgastados ou inexistentes e, sobretudo, ruas privatizadas por residências secundárias, seja por meio de obstáculos físicos ou ações inibidoras que desmotivam a passagem de não residentes dessas "casas de praia".

\section{CONSIDERAÇÕES FINAIS}

Como se viu ao longo do trabalho, no início do século XXI, a entrada de investimentos estrangeiros e/ou associados a brasileiros, aplicados no setor imobiliário e turístico na produção de residências secundárias, foi responsável pela intensificação da ocupação do litoral de Nísia Floresta; período esse quando igualmente é introduzido no litoral, o "condomínio fechado" como modalidade habitacional predominantemente destinada para público estrangeiro, o que redefiniu o uso e as formas dos DUO instalados na costa potiguar.

As diferentes formas de privatização dos espaços públicos litorâneos, identificadas nas praias de Pirangi do Sul, Búzios, Tabatinga, Camurupim, e Barreta (decks; piquetes; muretas; construções irregulares de residências secundárias e barracas em áreas não passíveis de ocupação; correntes e cercas; acessos estreitos e/ou a ausência dessas vias) estavam ocorrendo sem que o poder público promovesse ações inibidoras e restritivas, capazes de resguardar o direito de qualquer cidadão de livremente transitar pela beira mar, seja usuário de residências secundárias ou não. Em razão da ineficiência da atuação do poder público municipal, a presente pesquisa identificou que, determinadas vias de acesso às praias de Nísia Floresta, encontravam-se em condições de conservação comprometidas, sem iluminação pública, sem calçadas para pedestres, 
sem calçamento e em alguns casos, transformadas em canteiros de lixo e em valas de esgoto a céu aberto.

Em relação à ocupação do litoral, por omissão e acolhendo critérios escusos e particularistas, os órgãos públicos não atenderam padrões normativos à expansão urbana municipal, que regulassem territorialmente o uso e ocupação da cidade. Portanto, a apropriação do espaço público litorâneo em Nísia Floresta, ocorreu de forma privatizada em razão da não aplicação das normativas jurídicas existentes, considerando-se que o Plano Diretor do Município, dispõe de base legal a essa problemática.

Embora existindo um aparato jurídico e administrativo sobre o uso e ocupação do solo urbano litorâneo, o poder público municipal não foi eficiente na gestão dos bens públicos, evitando a apropriação privada das áreas e acessos à praia, colocando em evidência interesses escusos por parte de diferentes segmentos sociais, em parcerias ilegais entre o poder público e o capital privado.

É importante colocar que informações de domínio público, úteis para a análise geográfica da dinâmica imobiliária de Nísia Floresta, foram negadas pelo único Cartório do Município, infringindo-se assim o inciso XIV do art. $5^{\circ}$, da Constituição Federal (BRASIL, 1998) no qual "é assegurado a todos o acesso à informação", o que levanta a seguinte questão: porque e a quem interessa negar informações quanto ao loteamento do solo urbano de Nísia Floresta?

Em relação ao direito de uso e livre acesso à praia, constatou-se que os moradores permanentes de Nísia Floresta, não estavam encontrando apoio institucional suficientemente capaz de resguardar o pleno exercício desse direito elementar, constitucionalmente garantido. Órgãos como, por exemplo, a GRPU/RN, responsável pelo patrimônio da União, dispõe apenas de três fiscais para patrulhar toda a costa potiguar, com mais de $400 \mathrm{~km}$ de extensão (SILVA, 2010). O Projeto Orla (2006), por meio do Comitê Gestor, constituído por diferentes segmentos sociais - poder público municipal, estadual, federal e sociedade civil - não atuando de forma eficiente, servindo apenas para atender exigências legais, sem, portanto, efetivamente agir para se fazer valer a lei.

Com base no fato que a atividade turística e a residência secundária se constituem em indutores de urbanização e metropolização das áreas apropriadas, podese afirmar que o processo de urbanização e a metropolização dos municípios litorâneos 
da Região Metropolitana de Natal, beneficiados pelo PRODETUR/RN - Ceará-Mirim, Extremoz, Natal, Parnamirim e Nísia Floresta - se deu impulsionado pelo turismo, a partir da década de 1990 e intensificando-se nos anos 2000, no qual a residência secundária passa a se constituir em um dos fatores desse processo.

A partir das análises da presente pesquisa e com base na legislação pertinente, pode-se afirmar que a apropriação privada das áreas e acessos à praia, ao longo de todo litoral de Nísia Floresta ocorreu por negligência e com a conivência do poder público, na inobservância da legislação. A falta de articulação entre as diferentes esferas municipal, estadual e federal, implicou em ações ineficientes, pontuais, e inoperantes de forma a favorecer a apropriação privada dessas áreas destinadas ao livre acesso e uso do cidadão.

\section{REFERÊNCIAS}

ARENDT, H. A condição humana. Tradução de Roberto Raposo. 10. ed. Rio de Janeiro: Forense Universitária, 2005. 352 p.

ASSIS, L. F. Turismo de segunda residência: a expressão espacial do fenômeno e as possibilidades de análise geográfica. Revista Território. Rio de Janeiro. Ano VII - n. 11, 12, 13 - set./out., 2003.

BOYER, M. História do turismo de massa. Tradução de Viviane Ribeiro. Bauru: EDUSC, 2003. 170 p.

BRASIL. Constituição (1988). Constituição da República Federativa do Brasil. Brasília, DF: Senado Federal: Centro Gráfico, 1988. 292 p.

Lei 7.661, de 16 de maio de 1988. Institui o Plano Nacional de Gerenciamento Costeiro e dá outras providências.

Decreto 5.300, de 07 de dezembro de 2004. Regulamenta a Lei $\mathrm{n}^{\mathrm{o}}$ 7.661, de 16 de maio de 1988, que institui o Plano Nacional de Gerenciamento Costeiro - PNGC, dispõe sobre regras de uso e ocupação da zona costeira e estabelece critérios de gestão da orla marítima, e dá outras providências. 
Projeto orla: fundamentos para gestão integrada. Ministério do Meio Ambiente; Ministério do Planejamento, Orçamento e Gestão. Brasília: MMA, 2006. 74 p.

BRITO, M. T.; LIMA, J. A.; NÓBREGA JUNIOR, O; PONTES, B. M. S. Meioambiente e processo fundiário em conflito: Parnamirim e Nísia Floresta. Natal: UFRN/CCHLA, 1993. 126 p.

CAMARGO, H. L. Uma pré-história do turismo no Brasil: recreações aristocráticas e lazeres burgueses (1808-1850). São Paulo: Aleph, 2007. 383 p.

COLÁS, J. L. La residencia secundaria en España: estudio territorial de uso y tenencia. Barcelona, 2003. 440 p. Tese (Doutorado em Geografia). Facultat de Filosofia i Lletres. Universitat Autônoma de Barcelona.

CONSTRUÇÃO DE RESIDÊNCIAS EM BÚZIOS DESTRÓI DUNAS. Jornal Tribuna do Norte. Caderno Natal. Júnior Santos. Natal, 01 de maio de 2007. Disponível em: <http://tribunadonorte.com.br/noticia/construcao-de-residencias-embuzios-destroi-dunas/41002>. Acesso em: 05/09/2012, às 12hs.

CORBIN, A. O território do vazio: a praia e o imaginário ocidental. Tradução: Paulo Neves. São Paulo: Companhia das Letras, 1989. 385 p.

DE JESUS, G. M. Do espaço colonial ao espaço da modernidade: os esportes na vida urbana do Rio de Janeiro. Scripta Nova - revista eletrônica de Geografia y Ciencias Sociales. Universidade de Barcelona, 1 de agosto de 1999.

DISPUTA ENTRAVA PROJETO DE ÁREA DE LAZER EM MÃE LUIZA. Jornal Tribuna do Norte. Caderno Natal. Natal, 16 de dezembro de 2007. Disponível em: $<$ http://tribunadonorte.com.br/noticia/disputa-entrava-projeto-de-area-de-lazer-em-maeluiza/61431>. Acesso em: 05/09/2012, às 11 hs 04 min.

FERREIRA, A. L. de A.; SILVA, A. F. C. da. Dinâmica imobiliária e turismo: novas relações, novos riscos. Cadernos Metrópole 18. p. 109-133, 2 sem. 2007.

FONSECA, M. A. Tendências atuais do turismo potiguar: a internacionalização e a interiorização. In: ; NUNES, E.; CARVALHO, E. A.; FURTADO, E. M. (Orgs.). Dinâmica e gestão do território potiguar. Natal: EDFURN, 2007. p. 215-231.

Espaço, políticas de turismo e competitividade. Natal: EDUFRN, 2005. 224

p. 
GOMES, P. C. da C. A condição urbana: ensaios de geopolítica da cidade. Rio de Janeiro: Bertrand Brasil, 2002. 304 p.

HABERMAS, J. Mudança estrutural da esfera pública: investigações quanto a uma categoria da sociedade burguesa. Tradução de Flávio R. Kothe. Rio de Janeiro: Tempo Brasileiro, 2003. 397 p.

IBGE. Instituto Brasileiro de Geografia e Estatística. Domicílios recenseados, por espécie, segundo os municípios. Sistema de Delimitações de Setores. Espelho de Setores 2010, por Município. Rio Grande do Norte. Nísia Floresta. 2011.

LOPES JUNIOR, E. A construção social da cidade do prazer: Natal. Natal: EDUFRN, 2000.

MIRANDA, J. M. F. Evolução urbana de Natal em 400 anos 1599-1999. Coleção 400 anos. Vol. VII. Natal: Governo do Estado do Rio Grande do Norte; Prefeitura de Natal, 1999. $157 \mathrm{p}$.

MORAES, A. C. R. Contribuições para a gestão da zona costeira do Brasil: elementos para uma geografia do litoral brasileiro. 2. ed. São Paulo: Annablume, 2007. $232 \mathrm{p}$.

OLIVEIRA, M. R. L.; NICOLODI, J. A gestão costeira no Brasil e os dez anos do Projeto Orla. Uma análise sob a ótica do poder público. Revista da Gestão Integrada. V. 12, n. 1: p. 89-98, 2012.

SERPA, A. O espaço público na cidade contemporânea. São Paulo: Contexto, 2007. $201 \mathrm{p}$.

SILVA, C. A. da. Espaço geográfico versus espaço público: limites da cidadania. In: O Brasil, a América Latina e o mundo: espacialidades contemporâneas (II). OLIVEIRA, M. P.; COELHO, M. C. N.; CORREAA, A. M. (Orgs.). Rio de Janeiro: Lamparina; FAPERJ; ANPEGE, 2008. p. 435 - 446.

SILVA, K. O. A residência secundária e o uso do espaço público no litoral oriental potiguar. Dissertação (Mestrado em Geografia). Programa de Pós-Graduação e Pesquisa em Geografia, Centro de Ciências Humanas, Letras e Artes, Universidade Federal do Rio Grande do Norte. Natal, 2010, 167 p.

Condomínios fechados, residências secundárias e o uso do espaço público pelo capital imobiliário. Observatório de Inovação do Turismo - Revista Acadêmica. v. IV, n. 1, 2009. 15 p. 
SOUSA, P. M.. Análise do licenciamento ambiental como instrumento de política do meio ambiente no Rio Grande do Norte: período 1992-2003. Natal, 2005. 245 p. Dissertação (Mestrado em Arquitetura e Urbanismo). Centro de Tecnologia. Programa de Pós-Graduação em Arquitetura e Urbanismo. Universidade Federal do Rio Grande do Norte.

TULIK, O. Turismo e meios de hospedagem: casas de temporada. São Paulo: Roca, $2001.113 \mathrm{p}$.

VILLAÇA, F. Espaço intra-urbano no Brasil. São Paulo: Studio Nobel; FAPESP; Lincoln Institute, 2001.

YÁZIGI, E. O mundo das calçadas: por uma política democrática de espaços públicos. São Paulo: Humanitas/FFLCH6/USP; Imprensa Oficial do Estado, 2000. 546 p.

Recebido em: 05-09-2012.

Aprovado em: 05-10-2012. 